See discussions, stats, and author profiles for this publication at: https://www.researchgate.net/publication/248707360

\title{
European Union Lobbying and the Golden Cage of Post-Socialist Network Capitalism in Hungary
}

Article in JCMS Journal of Common Market Studies · June 2013 DOI: $10.1111 /$ jcms.12029

\section{CITATIONS}

10

1 author:

(3)

Dorottya Sallai

The London School of Economics and Political Science

7 PUBLICATIONS 15 CITATIONS

SEE PROFILE

Some of the authors of this publication are also working on these related projects:
READS

92

Project Clan state View project 


\title{
EU Lobbying and the Golden Cage of Post-Socialist
}

\section{Network Capitalism in Hungary*}

\author{
Dorottya Sallai
}

"This is the peer reviewed version of the following article: Sallai, D. (2013), European Union Lobbying and the Golden Cage of Post-Socialist Network Capitalism in Hungary. JCMS: Journal of Common Market Studies, 51: 948-964. doi: 10.1111/jcms.12029, which has been published in final form at:

http://onlinelibrary.wiley.com/doi/10.1111/jcms.12029/abstract

This article may be used for non-commercial purposes in accordance with Wiley Terms and Conditions for Self-Archiving."

Department of Management

King's College London

Franklin-Wilkins Building

150 Stamford Street

London

SE1 9NH

Dorottya.sallai@kcl.ac.uk

* I would like to thank Amy Verdun and Gerhard Schnyder for helpful comments and suggestions. In addition, the extremely valuable feedback by the anonymous reviewers is highly appreciated. 
Hungary is like sex was in our grandmother's days. It was there in the family, but nobody talked about it, because it was a taboo ${ }^{1}$."

\section{INTRODUCTION}

After the fall of the Berlin Wall, it took fourteen years before the first group of former socialist countries was able to join the European Union (EU). By this time, the increased competences of the supranational institutions meant that business-government relations had increasingly shifted from national towards European channels (Coen 2010). EU lobbying gradually has become crucial for business interests in their struggle to secure a 'friendly regulatory environment' (Bouwen 2004_b: 474).

Yet, despite the current trend of growing corporate representation at EU level, organizations from eastern Europe (EE) are under-represented in Brussels. Their participation in supranational policy-making is marginal and not effective (Charrad and Eisele 2005; Charrad 2010). Even at state-level - when member states engage in EU lobbying - EE countries generally have half as many contacts with supranational institutions than their Western counterparts (Panke 2012).

The puzzle of increasing importance of direct EU-level representation, but marginalisation of eastern European political engagement has rarely been addressed in existing literature.

Studies investigate Europeanization from three different perspectives. First, scholars focus on resources (Salamon and Siegfried 1977; Barney 2001) arguing that firm size and the

\footnotetext{
${ }^{1}$ Member of the Board in Large_hungarian_company02. Interview by author, 19.06.2011.
} 
availability of financial resources influences political capabilities most, hence the larger the firm, the greater the incentive to participate in politics (Olson 1965).

The second perspective approaches the ability of EU-level advocacy from an exchange paradigm (Salisbury 1969), claiming that only those are able to influence policy who can gain access to decision-making, either by providing information ${ }^{2}$ (Bouwen 2004_a) or technical expertise (Bouwen 2004_a; Eising 2007_a) to public officials.

The third approach looks at Europeanization from an institutional point of view, claiming that the domestic institutional background is a crucial determinant of political engagement. On the one hand the compensation thesis (Klüver 2010) claims that the national institutional structure determines supranational political engagement patterns negatively - so those organizations that have limited access to decision-making in their domestic environments, try to compensate this by pursuing direct EU-level lobbying. On the other hand the positive persistence theory explains a positive relation between domestic and EU-level representation (Beyers 2002; Eising 2007_b), claiming that good access to domestic legislative decision-making, stimulates European engagement. Conversely, those actors with little domestic access do not "seem to bypass their national governments in order to compensate for their weaknesses" (Beyers 2002: 608). More specifically, interest groups from pluralist counties adapted easily and quickly to the 'pluralist' (Schmidt 1999) or 'elite pluralist' (Coen 1997) system of the EU, whereas for those from corporatist (Coen 1998) or statist modes of coordination, it took longer to adapt to direct supranational lobbying.

Some recent views, however insist that the importance of the domestic institutional structure is overrated and has only a minor impact (Eising 2007_b), or no impact at all (Bernhagen and Michell 2009) on Europeanization. They claim that other factors, such as size (Bernhagen and Michell 2009) or the exposure to EU legislation (Eising 2007_b) have a more

\footnotetext{
${ }^{2}$ Theory of Access (Bouwen 2004_a)
} 
influential role. These studies conceptualise domestic institutions, but the variation between pluralist, corporatist and even statist countries remains secondary for them, because they all take for granted the Western democratic institutional framework.

Building on the Varieties of Capitalism (Hall and Soskice 2001) thesis as well as on the resource dependence model (Pfeffer and Salancik 2003), I argue that post-socialist capitalism has a decisive effect on firms' political strategies and Europeanization ability.

Empirical evidence of this article shows that network-based capitalism contributes to the development of a unique lobbying strategy, whereby lobbying is confined to the top of the organizational hierarchy and relies solely on relationships rather than professional public affairs (PA) know-how. I argue that this might lead to the permanent under-representation of eastern European business interests in EU governance.

In other words, despite the availability of resources and expertise, most large EE firms stay away from EU-level interest representation, because their unique lobbying style is not compatible with the multilevel decision-making system.

Furthermore, although the top-level lobbying approach allows EE firms to access decision-making in the domestic environment, it creates, at the same time a 'golden cage', which isolates them in the common market.

The article is structured as follows. The next section provides an overview of EE businesses' lobbying activities in Brussels. The third and fourth sections review the literature on comparative capitalism and informal networks and discuss the impacts of the institutional structure on lobbying styles and the importance of networks as key resources of lobbying. Section five discusses research design and data, the sixth presents the findings of the empirical analysis and a final section concludes.

\section{EE BUSINESSES IN BRUSSELS}

After nine years of full membership, practitioners and scholars alike agree that EE 
corporations are still largely missing from the EU-level interest representation system.

To mention but one indicator, in the Transparency Register of the European Commission and the European Parliament, those organizations are expected to register, which engage in lobbying in Brussels. By November 2012, out of 757 registered organizations under the 'companies and groups' category only 31 were from the ten post-socialist member states, Poland having the most registrants, with 11 firms, while Hungary and Romania each has four and all the others less.

Despite the fact that the figures from the register have to be used with caution due to its voluntary nature, they confirm the commonly acknowledged view that EE firms are drastically under-represented. Worse still, presence alone does not automatically mean influence. Scholars noted that EE business groups in Brussels mostly gather information about specific EU legislation and they create a "model of interest representation, where the exchange and ownership of information are more important than the actual impact on decision-making” (Borragán 2004: 262). Inexperience also impacts the relationships between interest groups and Eurogroups, making EE organizations dependent on EU umbrella organizations' expertise, know-how and networks. As a result "EE input is based on the exchange of information rather than an effective impact on policy outcomes" (Borragán 2004: 252). The following section investigates different factors that could lead to the marginalisation of EE interests in EU-level decision-making. 


\section{CAPITALISM AND LOBBYING}

Many scholars have tried to explain the nature of the new democratic and capitalist systems of post-socialist countries and the implications of transition on an institutional level. In this section it is argued that the unique nature of Hungarian capitalism - which is "hard to fit into one of the two boxes of the Varieties of Capitalism (VoC) framework" (Crouch, Keune et al. 2009: 12) - leads to a different type of lobbying, so strongly embedded in the domestic institutional context that it is hard to 'export' onto the supranational level.

Firms must adapt to their environments. Therefore, depending on context, they use different strategies when engaging in political interest representation. While pluralism represents a decentralised system of interest representation, where many small interest groups and individual firms compete for influence; in corporatist systems the relationship between government and a small number of encompassing interest organizations is structural (Peters 2005). Based on the VoC thesis (Hall and Soskice 2001), pluralism is commonly associated with Liberal Market Economies (LME) - through the political activity of lobbying - whereas corporatism is mostly used to describe interest representation in Coordinated Market Economies (CME). In liberal market economies firms operate in competitive market arrangements through formal contracting, whereas coordinated market economies are characterised by firms, which coordinate their activities through non-market relationships, such as networks (Hall and Soskice 2001).

One question arises, whether EE countries can be characterised as either LMEs or CMEs - hence can we expect pluralism or corporatism to prevail? Recent studies suggest that EE states do not fit any of these categories and can best be described as Dependent Market Economies (Nölke and Vliegenthart 2009). Thus if EE states do not fit under the categories of the LME/CME divide, then businesses cannot rely on associations like actors from CMEs, since they do not have institutionalised corporatism in their national capitals, or represent 
their own interests through individual lobbying as would actors from LMEs, because their structures for individual lobbying are immature and not institutionalised (McGrath 2008). Consequently, one would expect that the different domestic institutional arrangement will lead to different strategies in EU-level lobbying. Therefore this article conceptualises the mode of coordination in eastern European countries as 'post-socialist network capitalism' and claims that this domestic institutional structure has a decisive impact on how firms mobilize for EU lobbying.

\section{NETWORKS AND LOBBYING}

Although French firms lobby through informal networks, the Germans via corporatist associations while the British rely increasingly on professionalized direct lobbying (Thomson and John 2007: 5) - they all adapted to the 'elite pluralist', multilevel structure of EU lobbying and today use similar strategies in Brussels, creating a "distinct EU public policy and lobbying logic" (Coen 2009: 155).

When firms started to set up direct EU-offices, they first employed 'ex-Commission officials', hoping that their existing personal networks would positively impact interest representation (Mazey and Richardson 1993 as cited in Coen 2009: 155). By the 1990, however firms realised that networking alone cannot lead to lobbying success. Instead they need to "professionalize the government affairs function" (Coen 2009: 159), in order to harmonize lobbying activities within the internal organizational structure and to reinforce credibility with EU officials (Coen 2009).

Today, the "European business-government model is based on information dependency", where EU institutions require specialized knowledge, while firms develop direct representation strategies based on trust and accountability - being aware that "misrepresentation and bad practice may result in exclusion from the policy process"(Coen, 
Grant et al. 2010: 302).

In this institutional environment, corporations are used to universalism³ (Mungiu-Pippidi 2006) and formalized decision-making structures; therefore they consider lobbying as a professional tool for gaining competitive advantages. As a consequence, public affairs in Brussels are considered a long-term, proactive and legitimate process of well-defined professional activities.

In contrast, in EE firms, managers - being used to particularism ${ }^{4}$ and centralism - tend to have a feeling of 'powerlessness' towards political decision-making (Hrebenar, McBeth et al. 2008: 55) and consider lobbying a taboo. Lobbying is seen by business people as an ad hoc, short-term, reactive and often corrupt set of activities, done in different opaque ways, mostly through informal interpersonal networks (Kalnins 2005; Evanson 2008).

Here a distinction has to be made between the two rent-seeking activities of lobbying and corruption, since evidence shows that they can be substitutes, especially in developing and transition countries (Harstad and Svensson 2011).

Lobbying is generally referred to as an effort to influence the policy process (Baumgartner 1998), or public policy (Mahoney 2008), or to affect what the government does (Nownes 2006), but most of all it is 'the art of political persuasion' (Zetter 2008). It can encompass temporary and permanent actions in order to change legislation or keep the status quo and does not involve direct monetary exchange.

Corruption or bribery on the other hand is an attempt to "bend or get around" existing rules (Harstad and Svensson 2011: 46). It is a short-term, one-off and in most countries illegal activity that includes monetary exchange between firms and public officials. Lobbying is considered unethical if it includes "illegal payments or provision of other prohibited benefits"

\footnotetext{
${ }^{3}$ Universalism is "the norm and practice of individualistic societies, where equal treatment applies to everyone regardless of the group to which one belongs" (Mungiu-Pippidi 2006: 88)

${ }^{4}$ Particularism is where unequal treatment is the accepted norm in society. People do not expect equal treatment from the state, but treatment depends on status and position in society (Mungiu-Pippidi 2006: 88).
} 
(Kalnins 2005: 36). Ethical lobbying in EE states is not considered very effective, but instead "complicated, time consuming and expensive" without even guaranteeing results (Kalnins 2005: 40).

Yet, it would be misleading to argue that interest representation in EE countries is only done via corruption. Money is useful, but in itself does not necessarily lead to lobbying success. Evidence shows that in transition countries, informal personal networks give the basis of social organization, which may or may not go hand in hand with various levels and forms of corruption (Sajo 1998). Hence instead of corruption, networks between economic and political elites (Schoenman 2005; McMenamin and Schoenman 2007) provide the key channel for post-socialist lobbying.

Communism socialized people to use networks to avoid or overcomes troubles and seize opportunities, making the investment into network capital profitable (Sik and Wellman 1997: 13). And even though the political and economic system has changed, networks remained crucial for people to deal with decreasing state control, increasing opportunities and long-term uncertainty (Sik and Wellman 1997: 13).

Decision-making processes are not as transparent to the public as in WE democracies; therefore the transfer of insider information as part of the process of lobbying is inevitable. Information however is mostly shared within the network of acquaintances on an informal basis. Consequently, the majority of advocacy is done through informal interactions that might not include direct monetary exchanges, but are based on mutual social favours over a longer period of time.

If Anglo-Saxon interest representation is characterised by direct firm lobbying and German interest representation by corporatist negotiation, lobbying in eastern Europe can be best compared to the 'network capitalist' model of China (Boisot and Child 1996) or Russia (Puffer and McCarthy 2007). The latter model is characterised by a "personalised institutional 
order" (Boisot and Child 1996: 622). In post-socialist countries, politics and the economy are more closely interlinked than in traditional market economies. In business-government relations, parties have a decisive role and influence both in Poland (Schoenman 2005; McMenamin and Schoenman 2007) and Hungary (Stark and Vedres 2012). Parties need finances for political competition, whereas firms use networks for acquiring political concessions and government contracts (Stark and Vedres 2012). Furthermore, in Hungary "firms and parties have become organizationally entangled" through corporate boards (Stark and Vedres 2012: 700).

Whereas in classical capitalism state and economy is institutionally separated, in postsocialist systems their "boundaries are crossed" (Stark and Vedres 2012: 719). Consequently, in most former communist countries lobbying has a clientelist character. 'Clientelism' refers to the informal relationships between individuals and groups of unequal status, based on the mutual exchange of benefits (Kalnins 2005). People in the economic and political elites know each other, and particularistic interests are represented through personal relations and informal or semi-formal meetings.

While in the West, lobbying towards the state is crucial, since the "institutions of the state make and administer the rules that govern" economic interactions (Fligstein 1990: 31), in a network-based capitalist environment, the role of institutions as well the rule of law becomes ambiguous. The "public's belief in, and allegiance to" (Sajo 1998: 40), the rule of law is fragile. People survive through favouritism and personal social interactions, therefore laws may be "written in ways that enable insider dealing" (Sajo 1998: 40), and the governing elite might form the institutional environment according to their own particular interests.

Relationships are important everywhere, especially in those states where networks have traditional importance like in France. Yet, in post-communist countries lobbying is exclusively done through networking, as people rely on networks more than their counterparts 
in the developed capitalist countries and more than they did under communism (Sik and Wellman 1997: 1). As research on firm-party networks in Poland has shown those firms that did not or could not engage in relationships with party politicians, failed in their lobbying efforts (McMenamin and Schoenman 2007).

The question arises hence, what is the impact of networks on firms' public affairs strategy? If networks are so well-used in EE capitals, how can we explain that these firms do not transpose their lobbying strategy to the supranational level?

The resource dependence model (RDM) (Pfeffer and Aldrich 1972; Burt 1983; Pfeffer and Salancik 2003) can help to explain the link between informal networks and lobbying in the firms' organizational structure. RDM assumes that firms try to reduce their environmental uncertainties by using interpersonal relations as an instrument (Pfeffer and Salancik 2003) or a type of resource (Bandelj and Purg 2006: 588). Consequently it can explain the growing importance of relationships at times of economic and political change - when uncertainties increase considerably.

EU lobbying requires firms to use multiple strategies in the different legislative stages. While in the agenda-setting phase " $\mathrm{CEO} / \mathrm{Commissioner}$ contact is encouraged for the political momentum" (Coen 2009: 160) later in the policy formulation and implementation stages the middle management of government offices negotiates (Coen 2009) with lower level officials.

Empirical evidence in the following sections will highlight three major characteristics of post-communist lobbying that differentiates political engagement strategies of large Eastern firms from WE practices and limit their effectiveness at supranational level. First, lobbying at EE firms is done exclusively by top level management. Secondly, it is managed exclusively through informal inter-personal networks and third, this organizational arrangement of lobbying limits the reach of interest representation - making them unable to channel their interest onto the supranational levels. 


\section{RESEARCH DESIGN AND DATA}

This article is a case study, focusing on the in-depth investigation of the reasons why large Hungarian firms are relatively absent from EU-level lobbying. While a single case study cannot confirm a theory, in explanatory studies this model is useful in investigating a single phenomenon (Gerring 2004) especially in the stage of concept creation. I argue that the Hungarian case is presumably not unique. If the model about the impacts of post-socialist network capitalism on supranational lobbying is tested in the Hungarian context, then it can open the way for further hypothesis formation for lobbying and capitalism in general.

In the empirical study 50 semi-structured interviews were conducted in two phases. The first stage included 20 public affairs professionals in London and Brussels - who actively engage in EU lobbying at agencies or in-house departments of politically active corporations. Among the consultancies, a selection of multinationals and local independent agencies was targeted. London-based British firms were included in order to provide a benchmark for professional corporate lobbying. As the UK's pluralist and increasingly professional PA industry involves around 3000 practitioners, consultants and in-house experts (Thomson and John 2007) - it is similar to the 'elite pluralist' (Coen 1997) structure that characterises EU lobbying, at least in its professionalism. Here firms cannot rely on their contacts any more since "the quality of their argument is fundamental" (Thomson and John 2007: 5). As a result they can be used as a benchmark for professional lobbying.

In the second phase a further 30 top managers were interviewed in Hungary. This group included 13 CEOs of large Hungarian firms, 9 CEOs and PA directors of local subsidiaries of multinational companies (MNCs); political advisors, influential, domestic business people, non-governmental organizations and associations. Those large private and public businesses were targeted, which were considered to be affected by domestic and EU 
legislation. The aim was to find those people, who engage in lobbying as part of their job. During the contact phase it became evident that Hungarian firms generally do not have PA or lobbying departments. Therefore, the CEOs emerged in most cases as the most relevant interviewees. Respondents were asked about the tactics they engaged in, their strategy as well as their relationships with associations and the state. 


\section{FINDINGS}

In contrast to Brussels-based firms, Hungarian companies rarely set up direct EU offices, or use third party representation. Instead they tend to prefer national and sometimes European associational memberships. Indeed, out of the 13 interviewed large, Hungarian firms only four had direct memberships in European associations; one had a lobbyist in Brussels, while the rest had no representation at all.

Lobbyists in Brussels have confirmed that EU-level representation of EE firms is marginal. Most Brussels-based consultancies did not have any EE clients. Stakeholders in Brussels could name only a handful of large EE firms, active at EU level. Many interviewees argued that post-socialist firms represent themselves through national associations and try to free-ride on others' lobbying efforts instead of investing into costly direct representation ${ }^{5}$. Even so, empirical evidence shows that the influence of Eastern interest groups in EU-level associations remains limited, "due to their heterogeneity and underdeveloped domestic systems of interest intermediation" (Blavoukos and Pagoulatos 2008: 1159).

What holds for associations, also holds for firms. Weak influence goes hand in hand with PR-type activities and the lack of professional political and economic analysis even at EE firms, which have opened EU-offices ${ }^{6}$. Yet, consultants in Brussels and CEOs in Budapest have contrasting views on the reasons of limited EE presence. What consultants see as a result of ignorance and lack of sophistication in Brussels; business people in Budapest consider common business sense.

EE businesses operate in a fast changing, uncertain institutional environment, where formal institutions are weak and lobbying is often mistaken for corruption. Hungarian corporations consider interest representation as a tool for survival in their domestic

\footnotetext{
${ }^{5}$ This view was supported by consultant07, consultant08 and consultant10 (Interviews by author, 30.10.2009, 06.09.2009 and 23.11.2009 respectively).

${ }^{6}$ Consultant04, Interview by author, 15. 10. 2009.
} 
environments, but cannot quantify the value added of EU-level lobbying. Since they do not see what direct impacts Brussels have on their operations, they consider the uncertain results of an EU-level strategy a waste of time and money. Consequently, they choose not to invest in supranational engagement. Rather they try to influence the domestic implementation of EU legislation by lobbying their relevant execution orders ${ }^{7}$.

In London and Brussels there are two main factors that influence how much attention and money corporations allocate to lobbying. The first is the organisation's size or available resources (Coen and Dannreuther 2003; Beyers and Kerremans 2006; Beyers and Kerremans 2007; Bernhagen and Michell 2009) and the second is regulatory exposure (Eising 2007; Bernhagen and Michell 2009). Generally the bigger a company, the more it will spend on lobbying. Partly because large firms incorporate public affairs in their general communications activities seeing it as a tool to maintain a positive image (Thomson and John 2007); and because they are more significantly affected by legislation. Western corporations in heavily regulated industries are more likely to channel substantial financial and human resources towards lobbying, as they realise that their activities can be drastically affected by regulation.

In contrast in $\mathrm{EE}$, larger size or regulatory exposure does not lead to more professional lobbying among domestic firms. Even highly regulated companies that rely on public investment projects do not have PA/government offices - or even a dedicated professional dealing with government engagement; nor a declared separate budget for political involvement. At some EE companies there is a separate budget for 'constitutional expenses', but in these cases the budget is explicitly set aside for corruption purposes. Indeed, the term

\footnotetext{
${ }^{7}$ Supported by professor01, Interview by author, 31.07.2009
} 
'constitutional expenses' is used in business circles and usually means cash, but was first publicly referred to by a former CEO of the national Hungarian Power Companies Ltd. ${ }^{8}$

Business leaders in Hungary feel that there is not much they can do formally to influence the domestic legislative framework. When explaining the reasons for staying away from Brussels, many interviewees referred to their domestic difficulties in interest representation. The managing director at large_hungarian_company04 highlighted that:

„Politically nobody has a say in issues, policy issues are the responsibilities of the state. We do not employ lobbying groups to push those people to decide in other directions. If we have any insights that we want to communicate then I go to the ministry personally and tell them that we have a technical problem... But you do not try to influence the legal background."

This approach spills over to the EU level, as most of the interviewed CEOs argued that if they cannot reach certain objectives at the domestic levels, why would they even try at the supranational level? As interest representation was forbidden in the years of socialism, and transition brought weak formal institutions and a fast changing legislative environment, stakeholders often feel a state of anomie instead of security.

Indeed, EE firms' perception of lobbying as 'useless' conditions them to distance themselves from political engagement at EU-level. Not seeing the value of lobbying, they prefer non-engagement or ad hoc engagement to continuous, proactive, professional lobbying activities.

This hints at the importance of domestic institutional factors in shaping corporate lobbying strategies. The next section shows that different characteristics of the institutional environment lead to a difference in approaches towards political engagement, resulting in a different type of lobbying strategy among EE firms.

\footnotetext{
${ }^{8}$ See online article, Sághy 2009, available at

http://hvg.hu/hvgfriss/2009.15/200915_MILLIARDoS_KARoK_AZ_MVMNEL_Kozpenzek_gebinb
} 


\section{LOBBYING: THE PRIVILEGE OR BURDEN OF THE ECONOMIC ELITE?}

In this section we investigate the proposition that lobbying in EE firms is done exclusively by top level management, which naturally limits the reach of lobbying. All interviewed domestic firms in Hungary declared that they do not have an official political or lobbying strategy. Yet, when executives talk about interest representation, they mention issues they personally manage through lobbying people in their own networks. The nature of interest representation can be best illustrated with the words of a large Hungarian firm's director', who answered the following when asked whether his company had a written political strategy: "No, absolutely not, this is a real taboo. It exists but we do not even talk about it."

Discussions show that firms engage in lobbying on a daily basis, but they use informal channels instead of formal procedures. Managers rely both on their personal relationships and official positions in their lobbying strategy, so networking is "neither a private affair, nor a purely official contact" (Sik and Wellman 1997: 6). As a result, interest representation becomes an ambiguous and secretive activity. Business leaders have mixed feelings towards this part of their job. They talk about it with pride - since they are the key people, who hold the most important contacts and information, necessary for the representation of their firm's interests. But at the same time they feel that this privilege is sometimes a burden, since their own personal acquaintances are the inseparable assets of the company and they cannot trust anybody else in lobbying matters. It is difficult to draw a line between their personal and business lives. Furthermore they always have to excuse themselves and assure everyone that the lobbying they do does not include bribery or other unethical practices, even if it sometimes presumably does.

Beyond the non-professional nature of lobbying, one important difference between EU-level and Hungarian domestic lobbying is the 'currency' in which companies have to

\footnotetext{
${ }^{9}$ Large_hungarian_company02, Interview by author, 19.06.2011
} 
'pay' for accessing decision-making. As it was explained earlier, according to the exchange theory - in return for access to EU-level policy-making - interest organizations provide information to institutions (Bouwen 2002). Information about the domestic environment, the impacts of a legislative proposal at EU-level or expertise (Bouwen 2004_a), all provide valuable knowledge and the sense of legitimacy for decision-makers in Brussels.

In Hungary, on the other hand, policy making is not directly accessible for stakeholders. Public consultations and information exchange in legislative procedures are often superficial or vague. State-level negotiation structures and tripartite interest reconciliation although formally present, are not 'real' functioning institutions. In this environment, which is sometimes referred to as "fake corporatism" (King 2007: 309), firms have no other option than informally contacting state officials in order to get access to the policy process.

Executives channel political messages to policy-makers through personal relations, company boards as well as their networks in associations. Interviewees confirm that informal channels virtually always supplement associational representation. In their political function employers' organizations are much 'less capable of influencing economic policy than their counterparts in developed market economies" (Koltay and Neumann 2006: 56). Nevertheless they are an important official forum for networking. Being on the board of one of the largest employer associations - the Confederation of Hungarian Employers and Industrialists (MGYOSZ) - is an important and respectful position that many businessmen strives for. Despite the acknowledged organizational ineffectiveness of large boards, the social importance of board membership has led MGYOSZ to have a board of 40 people - 2 Chairs, 16 vice-chairs and 22 board members in 2012.

Hence, executives become key information channels, because in the post-socialist institutional environment, personal networks become the key resource for lobbying. Friends 
and relations provide the only access to information. In contrast to EU-level lobbying, where information gives access, here networks provide entry. As information from market players is rarely valued by decision-makers the exchange currency is money and / or social favours. Managers get information through their direct contacts to politicians and pay for the access by providing in-kind contribution to parties in the form of advertising campaigns or consultancy (Stark and Vedres 2012), promising to do something in return for the decision-maker, or rarely by paying the price in cash. Favours however are not always quantifiable in monetary terms or traceable in time. Paying private school fees for politicians' children or employing their relatives at the company may be two typical examples among the many that are spread over time and have no direct link with the act of political persuasion. As interviewees stated, both access and currency is inevitable for lobbying success.

As a result, even if firms wanted to use professional lobbying techniques to further their interests, they have to adapt to the local rules, since Western-type access goods (information and expertise) do not lead to success. Firms put public affairs into the hands of their CEOs, because they have the most reliable information about the company and therefore they are the ones who are taken most seriously by public or government officials. At the same time they are the only ones who also have the informal channels to be able to access top-level decision-makers, so lobbying becomes their exclusive task.

Here we have to distinguish between informal networking and corporate lobbying. Networking is widely used at every level of the company to overcome bureaucratic barriers or to seize personal and organizational opportunities. Informal networks are used to solve problems that formal channels will not or cannot address (Böröcz and Southworth 1998). Hence, employees manage their own formal and informal relations with lower level state officials and market players. These formal and informal networks at different levels of the organizational hierarchy complement each other, like layers of an onion. The lower the 
organizational hierarchy, the more formalized procedures become and less and less information is available about political strategy. In contrast to networking, corporate lobbying - in the sense of influencing the company's legal and institutional environment - is exclusively done by the top-layers of the organisation.

At most large Hungarian firms, even middle management does not know the directions of corporate political strategy, it is strictly kept at top levels. A Head of the Strategy Department at a large state-owned company ${ }^{10}$ explained that he does not know the political strategy of the firm and added:

"Directions and policy-level issues, as well as informal contacts are managed by the highest level management. Our CEO's main task is to have these contacts. It's kept in the higher regions..."

Consequently, instead of setting political objectives in business planning, "boards use the forum of meetings to discuss who knows who and therefore who should take on which issues" ${ }^{\prime 1}$. Hence, the management and communication of a firm's political strategy reflects the characteristics of its top executives. CEOs decide what type of information they share with their colleagues and what methods they use when they engage in lobbying. This is a completely non-transparent procedure.

As a Member of the Board ${ }^{12}$ at a large Hungarian company explained:

"The CEO can choose to keep all the contacts and distribute the information to his colleagues. Or he employs people who have good personal network capital. If he knows that a colleague knows a person, who is necessary for the company, then the colleague will get tasks that he can arrange through his relationship."

The effectiveness of network-based lobbying at the domestic level makes business

\footnotetext{
${ }^{10}$ Large_hungarian_company05, Interview by author, 02.07.2011

${ }^{11}$ Large_hungarian_company02, Interview by author, 19.06.2011

${ }^{12}$ Large_hungarian_company02, Interview by author, 19.06.2011
} 
leaders feel that they do not need intermediaries. When asked about the reasons of lobbying being confined to top level, former CEO of a subsidiary of a multinational ${ }^{13}$ explained that: "This is a small country, everybody knows everybody. Why should anybody fool themselves with having PA professionals?" Similar reasoning was used by a CEO of a large domestic firm ${ }^{14}$ when he explained the lack of professional monitoring procedures in his company.

Reference to the geographical extent of the country in relation to preferred lobbying methods, is not unique in Hungary. Interviews support that people in other post-socialist countries - despite some of them being very large (Poland) - have the same perception of smallness, because of the direct access to decision-makers via networks. The factor smallness hence seems to be more a subjective perception of size than a reality.

Indeed, people who believe that their direct influence in the domestic institutional environment is a consequence of their country's 'small' size, also think that they are not able to engage at EU-level for the same reason. Contrary to the measurable geographical size of a state, a country's self-perception of its size and importance (Thorhallson 2006) might have an influence on the perception of its own lobbying abilities. Perceptions however might be misleading. How well organizations are able to engage with EU institutions does not primarily have to do with the size of their country. Small WE countries - like the Netherlands or Belgium - have a lot more firms engaging in Brussels, than EE states. Conversely Poland, although perceives itself as "big and important" (Copsey and Haughton 2009) is not much more active in EU-level corporate lobbying than Hungary.

Therefore the main determinant of influence may not be size, but lobbying capabilities. As firms confine lobbying to the top, they limit the development of their capabilities and indirectly exclude themselves from supranational decision-making. In Hungary corporate leaders lobby through their own informal interpersonal networks,

\footnotetext{
${ }^{13}$ Multinational_in_Hungary02, Interview by author, 05.09.2011

${ }^{14}$ Large_hungarian_company04, Interview by author, 22. 06. 2011
} 
following unwritten rules, without any declared budget. They are not supported by professional public affairs departments and a centralised political strategy. It cannot be considered lobbying that lower level managers also try to influence state officials and network for the interests of the company in particular issues.

The position of lobbying at the top of the organisational hierarchy in Hungarian firms limits the reach of their lobbying activity. Not only, because the number of a CEO's contacts will be naturally finite, but also because the wide array of professional lobbying tools and strategies are not available to directors. Executives are limited in time, know-how as well as in the number of relations they have. This constitutes a particularly important handicap regarding the engagement with EU-level institutions.

Indeed, in contrast to scholars who investigate networks from the outsiders' point of view (Peng 2003), this study shows the impact of networks on insiders. Peng, who theorized firms' network-based organizational strategies, claims that networks will have an 'exclusionary' effect on outsiders and consequently they create barriers to entry. Yet, this article shows that on the one hand, network economies are penetrable for foreign companies which adapt to the local institutional environment and use networking strategies too - and on the other hand instead of being a barrier of entry, networks have a lock in effect, as they create a 'barrier to exit' for insiders. In other words, network-based strategies limit EE firms' international engagement.

\section{NETWORKS AS 'GOLDEN CAGES'}

The investigation of multinationals' lobbying strategies in EE can shed light on the question, whether the institutional context is a more important determinant of lobbying than the availability of resources. MNCs were among the first to open direct representation offices in 
Brussels, using professional PA methods for channelling their interests. In the Hungarian economy foreign MNCs have an influential role through FDI. They dominate the Budapest stock market and Hungarian firms rely on them for finance (Bohle and Greskovits 2007). Looking at foreign MNCs' behaviour constitutes a 'natural experiment', since they have the necessary resources as well as the know-how to use professional lobbying methods. So the question arises whether they try to achieve their goals the same way in Budapest as in Brussels, or do they adapt to the local networking games?

Informal networks are generally considered economically inefficient, since they are thought to fence insiders from external competition (World Bank 2001). Yet, the data presented in this paper show that, rather than excluding outsiders, the organizational structure of top-level network-based lobbying creates a 'golden cage' for insiders for two reasons. First, it forms a 'lock-in effect' for members, because they cannot develop professional lobbying capabilities and therefore they can achieve results only at the domestic level. Secondly, by being penetrable to more professional and resourceful foreign companies, domestic firms become exposed to lobbying competition and lose their competitive advantages in their own markets.

Interviews show that at the stage of entering post-socialist markets, subsidiaries of multinationals engage in relationship-based lobbying by paying mediators to "buy" access ${ }^{15}$. Yet, once they are in the market, they use two different approaches. On the one hand, they appoint CEOs, who either worked at state organizations before, or otherwise have strong interpersonal connections with the industry and the state. On the other hand, if the CEO is an expatriate foreign person, then he/she is supported by a senior government relations professional, who opens the doors for the executive.

As a former CEO at a foreign multinational's subsidiary in Hungary ${ }^{16}$ explained:

\footnotetext{
${ }^{15}$ Based on interview with the executive director of Hungarian_ngo02, by author 16.11.2011.

${ }^{16}$ Multinational_in_Hungary02, Interview by author, 05.09.2011
} 
"If multinationals want to arrange something, the CEO goes to see the minister not the PA director. The director or the team is just preparing documents for him."

Foreign and local top managers do not mingle, but rather engage in their own separate circle of 'friends'. Foreigners meet in international chambers of commerce and embassies, while domestic managers at domestic associations, social clubs and private gatherings ${ }^{17}$.

Multinationals adapt to the local networking game, but extend these with all their capabilities, including their professional lobbying know-how, financial and human resources. As a result, Hungarian business people feel that multinationals have an 'unfair' competitive advantage, because they have comparably larger resources, and because they often get extra state funding or tax-related financial support, when they enter the market.

In this respect, networks are not protecting local companies, nor are they excluding towards foreigners. Foreign companies are welcome in the networking game, as long as they play by the local rules. This hints at the importance of domestic determinants of lobbying.

${ }^{17}$ Multinational_in_hungary07, Interview by author, 07.03.2012 


\section{CONCLUSION}

Even though EU legislation increasingly affects the operation of businesses in eastern and western Europe, it is puzzling that businesses from the poorer half of the common market are seriously under-represented in influencing decision-making. The literature so far has not addressed this issue from the perspective of corporations. This study attempted to cover this gap and to explain the absence of Hungarian businesses from multi-level interest representation. Using resource dependence theory and the Varieties of Capitalism framework it was argued that in Hungary - where networks constitute the key resource of business lobbying - the nature of post-socialist capitalism forces firms to develop a distinctive lobbying strategy, which is highly effective in the domestic arena, but leads to exclusion at the supranational level. The Hungarian institutional environment makes formalized lobbying strategies less effective, as the public sector is not open to professional input from market players and public consultations are limited and vague. Consequently, policy analysis and legislative monitoring seems often unnecessary or ineffective for market players, since legislation changes from one day to the other.

Firms adapt their organizational structure to the institutional framework of postsocialism and position lobbying on top of the corporate hierarchy, in the hands of their executives. Empirical data - based on 50 semi-structured interviews - was analyzed to show that only top-level positioning together with informal, network-based lobbying strategies allows firms to directly influence policy or at least certain political decisions. In this environment, informal relationships give access to decision-making and the exchange currency in lobbying - instead of information - is money (in the form of party financing or corruption) or social favours. The system is efficient for insiders. Those, who have top level networks and money (or power) can exert influence. Firms feel that they do not have much room for manoeuvre in policy-making, but the little they have, is used most effectively. It was 
shown that although managers feel 'powerless', networking gives them access to politicians. Yet, the unpredictable nature of this strategy makes it risky or even impossible for them to build a long-term political strategy or professional capabilities for supranational engagement.

Consequently companies do not want to develop their lobbying capabilities any further, as they can arrange anything based on relationships, especially since they perceive their country as 'small'. This same perception on the other hand prevents them from engaging at the supranational level.

Indeed, as Hungarian firms confine lobbying to the top of the organisational hierarchy, they limit the development of their capabilities. Therefore, the exclusivity of top-level lobbying creates a 'golden cage' for domestic businesses. While it provides access at national level, it prevents domestic firms from transposing their engagement strategies at supranational level. The inability of corporations to develop professional PA capabilities together with the top-level positioning of informal practices puts a natural barrier on firms' lobbying effectiveness.

The door of the 'golden cage' however is open for outsiders. Whereas large domestic companies naturally have the networking assets through their socialist heritage and build on their managers' social capital, multinationals buy their entry through mediators. Once they are in, resourceful foreign firms adapt to the local lobbying strategies and master them so well that domestic competitors feel that MNCs even overtake them in their own game. This contradicts views that see networks mainly as a barrier to entry. Rather in Hungary networks are mainly a barrier to 'exit' the domestic market.

Given the limitations of this qualitative study, based on one post-socialist country, future research should test whether the 'golden cage' phenomenon applies to other transition economies as well. 


\section{REFERENCES}

Bandelj, N. and D. Purg (2006). "Networks as resources, Organizational Logic, and Change Mechanism: The Case of Private Business Schools in Post-Socialism." Sociological Forum 21(4): 587-621.

Barney, J. B. (2001). "Is the Resource-based "view" a useful perspective for strategic management research? Yes." Academy of Management Review 26(1): 41-56.

Baumgartner, F. R. a. L., Beth L. (1998). Basic Interests. New Jersey, Princeton University Press.

Bernhagen, P. and N. J. Michell (2009). "The Determinants of Direct Corporate Lobbying in the European Union." European Union Politics 10(2): 155-176.

Beyers, J. (2002). "Gaining and seeking access: the European adaption of domestic interest associations." European Journal of Political Research 41(5): 585-612.

Beyers, J. and B. Kerremans (2006) Critical Resource Dependencies and the Europeanization of Domestic Interest Groups. Working Paper Series 20

Beyers, J. and B. Kerremans (2007). "Critical resource dependencies and the Europeanization of domestic interest groups." Journal of European Public Policy 14(3): 460-481.

Blavoukos, S. and G. Pagoulatos (2008). "'Enlargement Waves' and Interest Group Participation in the EU Policy-Making System: Establishing a Framework of Analysis." West European Politics 31(6): 1147-1165.

Bohle, D. and B. Greskovits (2007). "Neoliberalism, embedded neoliberalism and neocorporatism: Towards transnational capitalism in Central-Eastern Europe." West European Politics 30(3): 443-466.

Boisot, M. and J. Child (1996). "From Fiefs to Clans and Network Capitalism: Explaining China's Emerging Economic Order." Administrative Science Quarterly 41(4): 600-628.

Borragán, N. P.-S. (2004). "EU accession and interest politics in central and Eastern Europe." Perspectives on European Politics and Society 5(2): 243-272.

Bouwen, P. (2002). "Corporate lobbying in the European Union: the logic of access." Journal of European Public Policy 9(3): 365-390.

Bouwen, P. (2004). "Exchanging access goods for access: a comparative study of business lobbying in the European Union Institutions." European Journal of Political Research 43(3): $337-369$.

Bouwen, P. (2004). "The Logic of Access to the European Parliament: Business Lobbying in the Committee on Economic and Monetary Affairs." Journal of Common Market Studies 42(3): 473-495. 
Böröcz, J. and C. Southworth (1998). "Earnings Effects of Formal and Informal Social Network Resources under Late Socialism in Hungary, 1986-87." The Journal of SocioEconomics 27(3): 401-425.

Bryman, A. (2004). Social Research Methods, Oxford University Press.

Burt, R. S. (1983). Corporate profits and cooptation: Networks of market constraints and directorate ties in the American economy. New York, Academic Press.

Charrad, K. (2010). Participants or Observers in European Governance? Civil Society Lobbyists from Central and Eastern Europe in Brussels. N. V. M. Company. Munich, Nomos. 4.

Charrad, K. and G. Eisele (2005). Civil Society Actors from Central and Eastern European Countries in European Network Governance. The Institutional Shaping of EU-Society Relations. University of Manheim.

Coen, D. (1997). "The evolution of the large firm as a political actor in the European Union." Journal of European Public Policy 4(1): 91-108.

Coen, D. (1998). "The European Business Interest and the Nation State: Large-firm Lobbying in the European Union and Member States." Journal of Public Policy 18(1): 75-100.

Coen, D. (2009). Business Lobbying in the European Union. Lobbying the European Union: Institutions, Actors, and Issues. D. Coen and J. Richardson. New York, Oxford University Press.

Coen, D. (2010). European Business-Government Relations. The Oxford Handbook of Business and Government. D. Coen, W. Grant and G. Wilson. Oxford, Oxford University Press.

Coen, D. and C. Dannreuther (2003). Differentiated Europeanization: Large and Small Firms in the EU Policy Process. The Politics of Europeanization. K. Featherstone and C. M. Radaelli. Oxford, Oxford University Press.

Coen, D., W. Grant, et al. (2010). Political Science Perspectives on Business and Government. The Oxford Handbook of Business and Government D. Coen, W. Grant and G. Wilson. New York, Oxford University Press.

Copsey, N. and T. Haughton (2009). "The Choices for Europe: National Preferences in New and Old Member States." Journal of Common Market Studies 47(2): 263-286.

Crouch, C., M. Keune, et al. (2009). Three Cases of Changing Capitalism: Sweden, Hungary, and the United Kingdom. Innovation in Local Economies. C. Crouch and H. Voelzkow. Oxford, Oxford University Press.

Eising, R. (2007). "The access of business interests to EU institutions: towards élite pluralism?" Journal of European Public Policy 14(3): 384-403. 
Eising, R. (2007). "Institutional Context, Organizational Resources and Strategic Choices: Explaining Interest Group Access in the European Union." European Union Politics 8(3): 329-362.

Evanson, K. R. (2008). "Economic interest groups and the consolidation of democracy in the Czech Republic." Journal of Public Affairs 8(1-2): 33-49.

Fligstein, N. (1990). The transformation of corporate control, Harvard University Press.

Galgóczi, B. (2003). "The impact of multinational enterprises on the corporate culture and on industrial relations in Hungary." South-East Europe Review 1(2): 27-44.

Gerring, J. (2004). "What Is a Case Study and What Is It Good for?" American Political Science Review 98(2): 341-354.

Hall, P. A. and D. Soskice (2001). Varieties of Capitalism: The Institutional Foundations of Comparative Advantage, Oxford University Press.

Harstad, B. and J. Svensson (2011). "Bribes, Lobbying, and Development." American Political Science Review 105(1): 46-62.

Hrebenar, R., J. , C. McBeth, H., et al. (2008). "Interests and lobbying in Lithuania: a spectrum of development." Journal of Public Affairs 8(1-2): 51-65.

Kalnins, V. (2005) Parliamentary Lobbying between Civil Rights and Corruption: an insight into lobbying practice in Latvia and recommendations for the Saiema; according to the situation of July, 2004.

King, L. (2007). Central European capitalism in comparative perspective. Beyond Varieties of Capitalism: Conflict, Contradictions and Complementaries in the European Economy. B. Hancké, M. Rhodes and M. Thatcher. Oxford, Oxford University Press.

Klüver, H. (2010). "Europeanization of Lobbying Activities: When National Interest Groups Spill Over to the European Level." Journal of European Integration 32(2): 175-191.

Koltay, J. and L. Neumann, Eds. (2006). In Focus: Industrial Relations in Hungary. The Hungarian Labour Market - Review and Analysis 2006. Budapest, Institute of Economics, Hungarian Employment Foundation (HAS).

Mahoney, C. (2008). Brussels versus the Beltway - Advocacy in the United States and the European Union. Washington D.C., Georgetown University Press.

McGrath, C. (2008). "The development and regulation of lobbying in the new member states of the European Union." Journal of Public Affairs 8(1-2): 15-32.

McMenamin, I. and R. Schoenman (2007). "Together Forever? Explaining Exclusivity in Party-Firm Relations." Political Studies 55(1): 153-173.

Mungiu-Pippidi, A. (2006). "Corruption: Diagnosis and Treatment." Journal of Democracy 17(3): 86-99. 
Nownes, A. J. (2006). Total Lobbying. Cambridge, Cambridge University Press.

Nölke, A. and A. Vliegenthart (2009). "Enlarging the Varieties of Capitalism: The Emergence of Dependant Market Economies in East Central Europe." World Politics 61(4): 670-702.

Olson, M. (1965). The logic of collective action: public goods and the theory of groups. Cambridge, Harvard University Press.

Panke, D. (2012). "Lobbying Institutional Key Players: How States Seek to Influence the European Commission, the Council Presidency and the European Parliament." Journal of Common Market Studies 50(1): 129-150.

Peng, M. W. (2003). "Institutional Transitions and Strategic Choices." The Academy of Management Review 28(2): 276-295.

Peters, G. B. (2005). Institutional Theory in Political Science: The 'New Institutionalism'. Gosport, Hampshire, Ashford Colour Press Ltd.

Pfeffer and Aldrich (1972). "Size and Composition of corporate boards of directors." Administrative Science Quarterly 17(2): 218-228.

Pfeffer, A. and R. G. Salancik (2003). The External Control of Organizations, Stanford University Press.

Puffer, S. M. and D. J. McCarthy (2007). "Can Russia's state-managed, network capitalism be competitive? Institutional pull versus institutional push." Journal of World Business 42(1): 113.

Sajo, A. (1998). "Corruption, Clientalism, and the Future of the Constitutional State in Eastern Europe." East European Constitutional Review 37(2): 39-42.

Salamon, M. L. and J. J. Siegfried (1977). "Economic Power and Political Influence." The American Political Science Review 71(3): 1026-1043.

Salisbury, R. H. (1969). "An Exchange Theory of Interest Groups." Midwest Journal of Political Science 13(1): 1-32.

Schmidt, V. A. (1999). National Patterns of Governance under Siege: The Impact of European Integration. The Transformation of Governance in the European Union. B. Kohler-Koch and R. Eising. London, Routledge.

Schoenman, R. (2005). "Captains or Pirates? State-Business Relations in Post-Socialist Poland." East European Politics and Societies 19(1): 40-75.

Sik, E. and B. Wellman (1997). Network Capital in Capitalist, Communist and PostCommunist Countries. Networks in the Global Village. B. Wellman. Boulder, Westview Press. 
Stark, D. and B. Vedres (2012). "Political Holes in the Economy: The Business Network of Partisan Firms in Hungary." American Sociological Review 77(5): 700-722.

Thomson, S. and S. John (2007). Public Affairs in Practice - A practical guide to lobbying. London, Kogan Page Ltd.

Thorhallson, B. (2006). "The Size of States in the European Union: Theoretical and Conceptual Perspectives." Journal of European Integration 28(1): 7-31.

World Bank (2001). World Development Report 2002: Building Institutions for Markets. New York, Oxford University Press.

Zetter, L. (2008). The Art of Political Persuasion, Harriman House Ltd. 